\title{
Analysis of performance of a converted electric
}

\section{vehicle}

\author{
Análisis de desempeño de un vehículo eléctrico transformado
}

E. A. Salazar-Marín iD; J. F. Arroyave-Londoño iD; Moreno, I. Y. Moreno-Ortiz iD

\begin{abstract}
Colombia, like other developing countries has been incorporating different electrical vehicles to the automotive national market. While the acquisition of a brand new electric vehicle is still expensive, transformation from used traditional vehicles (combustion) to electrical vehicles has become an interesting economical option. This work presents a performance evaluation of a transformed vehicle from its combustion version. The theoretical and experimental analysis (in rugged geographical reliefs such as Colombia) are necessary to consolidate the validity of this type of proposals at technical, economic and environmental impact levels. The procedure of an electric conversion presented herein showed significant mitigation of greenhouse gases owing to the renunciation of 6,54 $\mathrm{L}$ per $100 \mathrm{~km}$ and hence avoiding CO emissions: $1,808 \mathrm{~g} / \mathrm{km}$ and THC + NOx: $0,652 \mathrm{~g} / \mathrm{km}$. The procedure included selection of both suitable car (low weight) and electric conversion kit, as well as assembly design, disassembly of combustion system, implementation of electric components. Additionally, experimental tests were performed to determine the behavior with respect to power under some load demands validating the proposed traction model.
\end{abstract}

Index Terms - Electric vehicle operation savings; greenhouse effect; renewable energies; sustainable transportation; technological transformation.

Resumen- Colombia, como otros países en desarrollo, ha venido incorporando diferentes vehículos eléctricos en el mercado nacional automotriz. Mientras, la adquisición de un nuevo vehículo eléctrico sigue siendo costosa, la transformación de vehículos tradicionales usados (combustión) a vehículos eléctricos se ha vuelto una opción económica e interesante. Este trabajo presenta una evaluación de rendimiento de un vehículo transformado a partir de su versión de combustión. Los análisis teóricos y experimentales en relieves geográficos accidentados como Colombia son necesarios para consolidar la validez de este tipo de propuestas a niveles de impacto técnico, económico y ambiental. El procedimiento de una conversión eléctrica

This manuscript was sent on March 12, 2019 and accepted on March 11, 2020. This work was supported by Technological University of Pereira Research Vice-rectory of investigations.

E. A. Salazar-Marín; J. F. Arroyave-Londoño; Moreno, I. Y. MorenoOrtiz. work as professors of Technology Faculty, Mechanical Technology program, CP 660003. They all belong to the research group of Mechanical Technology_ (email: yes@utp.edu.co, jfa@utp.edu.co, edgarsalazar@utp.edu.co). presentada aquí mostró una significativa mitigación de gases de efecto invernadero debido a la renuncia al uso de $6,54 \mathrm{~L}$ por 100 km, y de ahí se evita emisiones de CO: $1,808 \mathrm{~g} / \mathrm{km}$ de CO y 0,652 $\mathrm{g} / \mathrm{km}$ de THC + NOx. El procedimiento incluyó la selección tanto del carro apropiado (bajo peso) como del kit de conversión eléctrica, y también el diseño del ensamblaje, el desmontaje del sistema de combustión y la implementación de componentes eléctricos. Adicionalmente, se realizaron pruebas experimentales para determinar el comportamiento con respecto a la potencia en algunas solicitudes de carga que validan el modelo de tracción plantada.

Palabras claves- Ahorros en la operación de vehículos eléctricos; efecto invernadero; energías renovables; transporte sostenible; transformación tecnológica.

\section{INTRODUCTION}

$\mathrm{T}$ HE harmful impact generated by traditional transport (combustion) on the environment and human health is increasingly evident. Recently, a study published in various media states that: "For decades, pollution and its harmful effects on people's health, the environment, and the planet have been neglected both by Governments and the international development agenda. Yet, pollution is the largest environmental cause of disease and death in the world today, responsible for an estimated 9 million premature deaths" (The Lancet magazine [1]). This amount represents $16 \%$ of all premature deaths worldwide.

According to the same publication deadly victims of pollution are mostly the poor and the vulnerable since $92 \%$ of deaths occur in low - and middle - income countries. Children are the most affected. In addition, pollution costs the global economy 4,6 trillion USD per year, equivalent to $6,2 \%$ of global economic output.

Transportation is not only the main responsible of effects over human health, but also the principal source of greenhouse gases.

For instance, in United States a study affirms that Transport supplies $29 \%$ of total greenhouse gases [2]. 


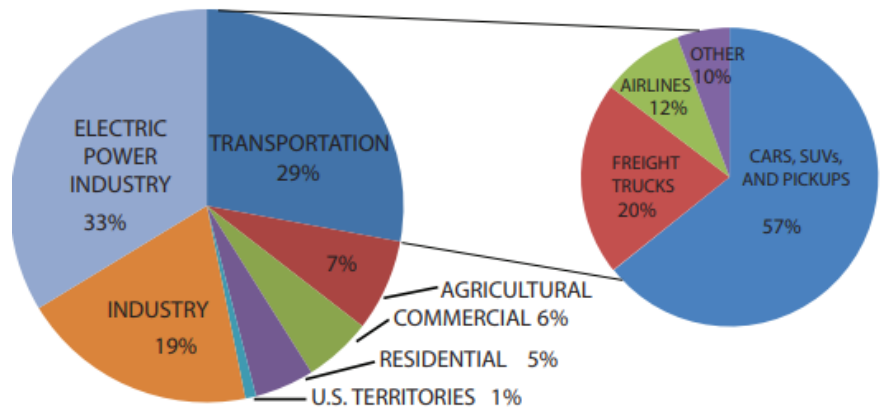

Fig. 1. Transportation shares of GHG emissions in the United States. [Source: U.S. Department of Transportation, Report to Congress, 2010] [2]

Other studies have shown how the growth of cities and its respective increase of vehicles and industry have made the problem worse [3]. The goal of this investigation is to present a technically and economically feasible alternative for an electric vehicle and to positively contribute to health and mitigation of greenhouse emissions.

Several electrical conversions have been carried out in countries like Mexico, Peru, Ecuador and Venezuela. Most of them without theoretical analysis and experimental test. They only show the functioning of vehicle generally in flat road. Rodríguez, et al [4] do an analysis of behavior of different electric vehicles over topology of Medellín (Colombia). González, et al. [5] describes a methodology to convert a combustion to electric vehicle without behavior analysis. Other studies [6] analyze different standard ways to measure the vehicles autonomy, but they do not incorporate power traction analysis. Emphasis on drivetrain has been presented in conversion of a conventional vehicle to a hybrid electric vehicle (HEV) [7] as well as conceptual design of electric vehicles [8].

Developed countries like Spain or Portugal have also promoted this kind of conversions, with some studies focusing on the design of power control system [9]. However, there is a pending task: the inclusion of the vehicle traction model validated by experimental tests (laboratory and road tests) that assess reliability of the car on the Latin American relief. The objective of the present work is to provide key theoretical and experimental information for the electric conversion of vehicle in the Colombian context.

This paper has the following structure: Section II reports costs and relevant characteristics of existing electric vehicles in the Colombian market. Section III presents the vehicle to be electrically converted and its corresponding power model. Section IV explains the procedure of electric conversion. Section $\mathrm{V}$ details results from performance tests and finally conclusions are given in Section VI.

\section{ELECTRIC VEHICLES}

The Electric vehicle option has existed since the last century, but for many reasons (mainly economic interests), the appropriate development has not been possible. Currently, the new policies in many countries and the technological innovations have allowed a rebirth of electric vehicles.
Table I presents a summary of most commercial electric vehicles in Colombia.

Various companies, such as Tesla, have been investing on research and technological development that improve the characteristics (autonomy, power, speed) and reduce costs, which allow to match and exceed (in some aspects) the performance of a combustion vehicle. In Latin America, electric vehicles still have a high cost for the end user, mainly due to the factory price and the importation related costs.

TABLE I

MOST SOLD ELECTRIC VEHICLES (2019)

\begin{tabular}{cccccc}
\hline \hline Characteristics & BYD & BMW & $\begin{array}{c}\text { Vehicles } \\
\text { Kangoo }\end{array}$ & Kia \\
& E6 & $\mathbf{i 3}$ & ZE & soul & Twizie \\
\hline Battery kWh & 82 & 33 & 24 & 27 & 8 \\
Power HP & 121 & 170 & 60 & 110 & 17 \\
Torque Nm & 449 & 249 & 226 & 250 & 57 \\
Autonomy km & 400 & 250 & 170 & 250 & 80 \\
Cost COP \$ & 150 & 160 & 85 & 129 & 40 \\
million (2018) & 7 & 7 & 8 & 9 & 24 \\
Sold units (2019) & & & & & \\
\hline \hline
\end{tabular}

Fig. 2. Electric vehicles (Table I).

\section{TESTED VEHICLE}

A Chevrolet Sprint (Suzuki Swift in USA) has been chosen for the conversion, due to its low weight and widespread commercialization in Latin-American context (Fig. 3).

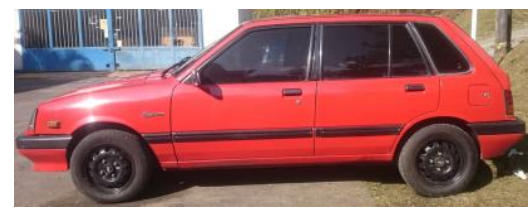

Fig. 3. Testing Vehicle

Car specifications \& technical data (combustion version):

Tare weight: $675 \mathrm{~kg}$, power: $46,8 \mathrm{~kW}$, weight/power ratio: 14,43. Engine displacement: $993 \mathrm{~cm}^{3}$.

Traction dynamic of this vehicle has been analyzed to establish power requirements, depending on characteristics of typical slopes in Latin America (Andes Mountains).

Equation (1) [9] represents the model to calculate Power (Watt) under different load conditions, involving resistive forces such as weight, rolling, aerodynamics and acceleration.

$$
\text { Power }=\left[W \sin \theta+C_{r} W \cos \theta+\frac{1}{2} \rho S K_{a} V^{2}+m a\right] V
$$

Where: $W$ (weight), $\theta$ (road slope), $C r$ (rolling coefficient), 
$\rho$ (air density), $S$ (cross section), $K_{a}$ (aerodynamics factor), $m$ (mass), $a$ (acceleration), $V$ (velocity).

Cross section of vehicle was determined using a sketch of frontal image with CAD (Fig. 4).

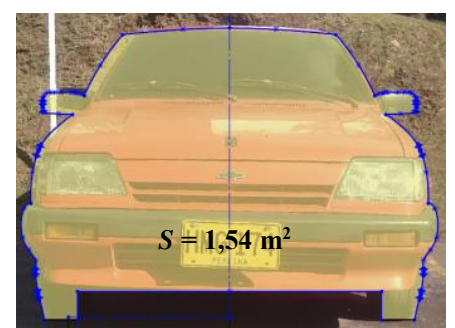

Fig. 4. Cross section of vehicle

Fig. 5 presents behavior of power and torque versus vehicle velocity (and RPM motor), taking into account the following values: $\mathrm{m}=675 \mathrm{~kg}$ (tare weight) $+350(5$ passengers $\mathrm{x} 70 \mathrm{~kg})$ $=1025 \mathrm{~kg}, C_{r}=0,02, K_{a}=0,26, a=0, S=1,54 \mathrm{~m}^{2}, \theta=10 \%$ and flat road.

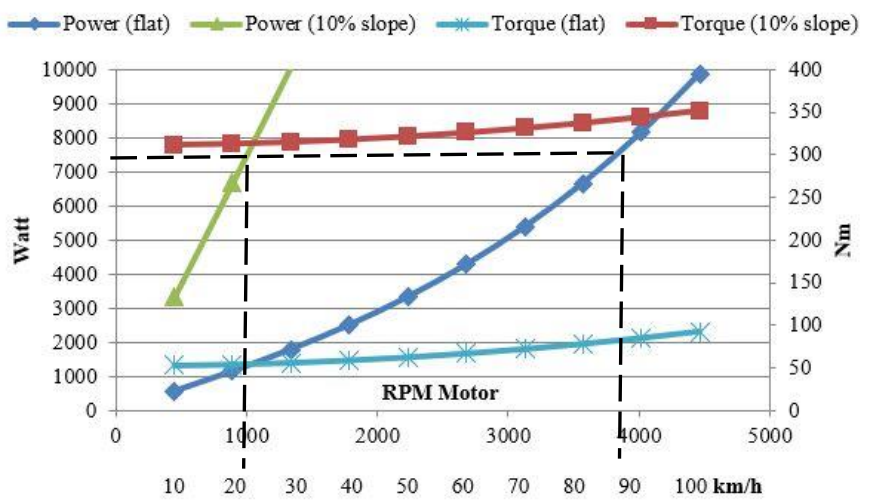

Fig. 5. Power and torque vs velocity and RPM motor (Eq. (1))

The objective of our electric vehicle is to overpass $80 \mathrm{~km} / \mathrm{h}$ in favorable conditions (flat road). An electric motor of 7,5 kW (10 HP) can achieve this goal (Fig. 5). However, vehicle will move at $23 \mathrm{~km} / \mathrm{h}$ on a high slope $(10 \%)$. On an average Colombian road, gearbox is necessary to supply the required torque under demanding load conditions.

Steps of electric conversion are the following.

\section{A. Base vehicle tests}

PEMS tests (Portable Emissions Measuring Systems) determined how much pollution was emitted to the atmosphere with the assistance of the measuring equipment of gas and combustible consumption of petrochemical company Ecopetrol (as part of a project called: Determination of the impact of E20 use in the Colombian vehicle park). The protocol NEDC (New European Driving Cycle) has been employed for Dynamics Tests (fuel consumption and pollutant emissions). Fig. 6 presents the employed cycle.

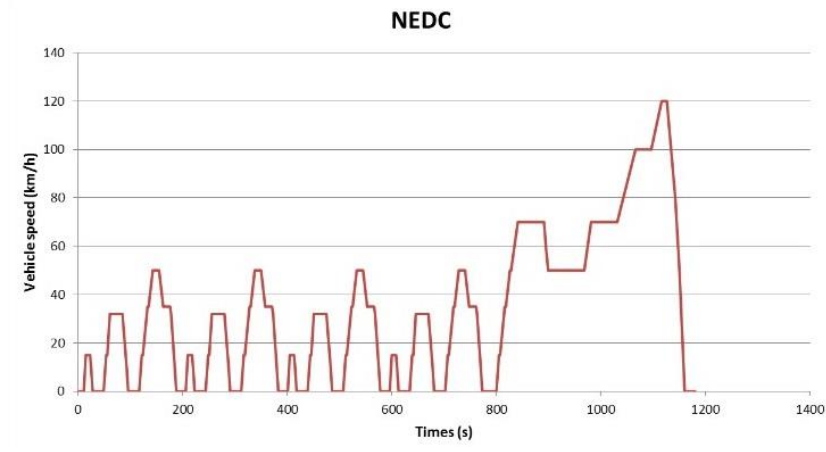

Fig 6. Driving cycles: NEDC. Urban (ECE), Extra Urban (EUDC)

In these tests, average fuel consumption has been 57,78 $\mathrm{km} /$ gallon $(6,54 \mathrm{~L} / 100 \mathrm{~km})$. Regarding pollution gases the results were: CO: $1,808 \mathrm{~g} / \mathrm{km}$, THC + NOx: 0,652 g/km. These values surpass authorized limits. According to Worldwide Emissions Standards (Passenger Cars and Light Duty) [9], the limits (Euro 4) are CO: $1,0 \mathrm{~g} / \mathrm{km}$ and THC + NOx: $0,3 \mathrm{~g} / \mathrm{km}$.

In Colombia, vehicles are evaluated according to Euro 2 (Resolution 910 of 2008), which determines limits, such as CO: $2,20 \mathrm{~g} / \mathrm{km}$ and HC+NOx: $0,50 \mathrm{~g} / \mathrm{km}$. The tested vehicle also surpasses these values.

\section{B. Electrical kit}

According to traction dynamic analysis (Fig. 5), a $10 \mathrm{HP}$ motor is selected with an electric system of $72 \mathrm{Vdc}$ with next components

- AC controller 72V 400A

- Isolated DC-DC Converter 72/12-30

- Charger CH4100 72V 25A

- Electronic Accelerator

- Round Battery Discharge Indic

- Motor AC HPQ7.5YBE-72

- Vacuum pump 12V brake

- Lithium battery Box with BMS (72 Vdc, $150 \mathrm{Ah})$

Motor curves are provided by manufacturer (Fig. 7). Power curve shows that motor supplies $8 \mathrm{~kW}$ with $90 \%$ efficiency and Torque $30 \mathrm{Nm}$.

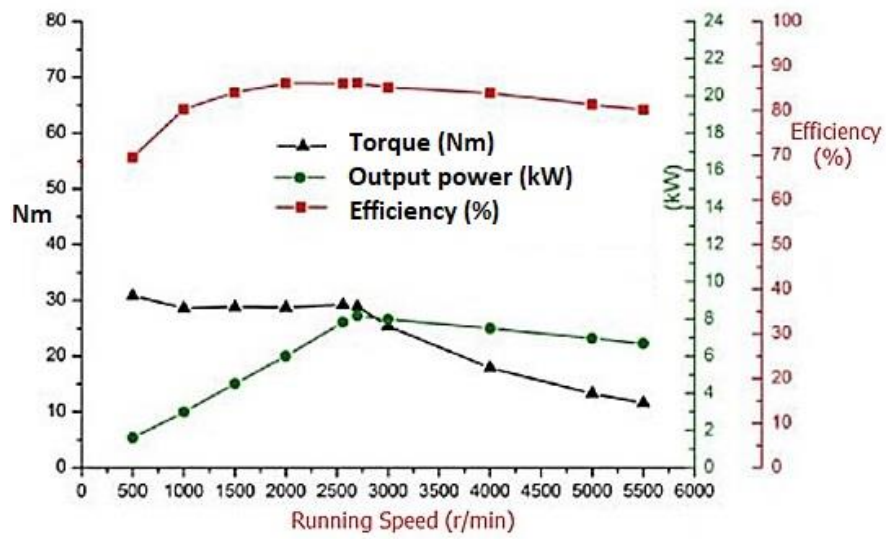

Fig 7. Characteristics Curves of motor 
Unlike combustion motor, electric motor supplies maximum torque at low revolutions, allowing to satisfy high torque demands in starting without consumption of high levels of power. However, a gearbox is necessary to high slopes. Table II presents transmission relations of the gearbox.

TABLE II

\begin{tabular}{cc} 
GEARBOX AND TRANSMISSION RELATIONS \\
\hline Gears & $\begin{array}{c}\text { Transmission } \\
\text { relation }\end{array}$ \\
\hline 1 & 3,41 \\
2 & 1,89 \\
3 & 1,28 \\
4 & 0,91 \\
5 & 0,75 \\
reverse & 2,91 \\
Last axis & 4,38 \\
\hline
\end{tabular}

For instance, a motor torque of $30 \mathrm{Nm}$ (maximum torque, Fig. 7) can be amplified to 448 N.m in first gear for satisfice high demands on high slopes (Fig. 5). Fig. 8 presents the connection scheme of the required electrical system.

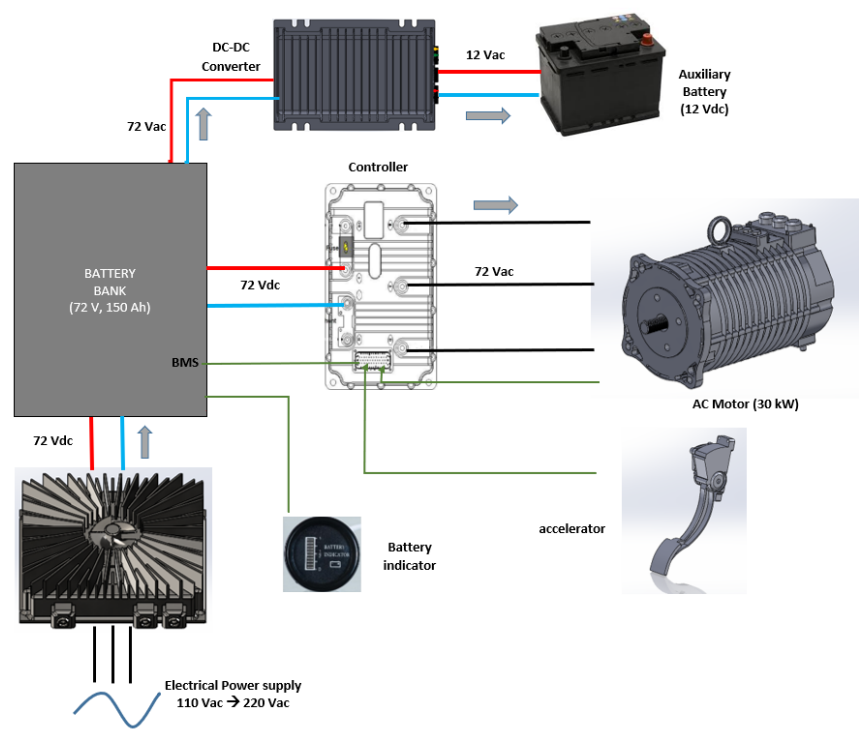

Fig 8. Connections scheme

\section{Preliminary tests of electric kit}

Previous to installation of system, motor tests without load were performed to verify components state and system operation. Principal Battery must be connected to auxiliary 12 Vdc signal (auxiliary battery) by means of BMS (battery management system).

Electrical current demanded by the motor was measured in these no-load tests. Peak current of $56 \mathrm{~A}$ and $72 \mathrm{~V}$ represents a consumption of $4032 \mathrm{~W}$. Initial tests corroborated both satisfactory electrical connections. Charge tests were made to supply power of $1700 \mathrm{~W}$ in connection of $120 \mathrm{Vac}$ (14 A). In this case, the principal battery is almost full. Therefore, a demand of higher current will be expected when battery is unloaded.

\section{Disassembly of combustion motor}

Prior to combustion motor complete removal, fuel and air filters and tubes need to be unplugged, and some components need to be removed (distributor, carburetor, radiator, exhaust tube, fuel tank, radiator fan belt, alternator and starting motor). Only original gearbox will be used in the electric assembly (Fig. 9).

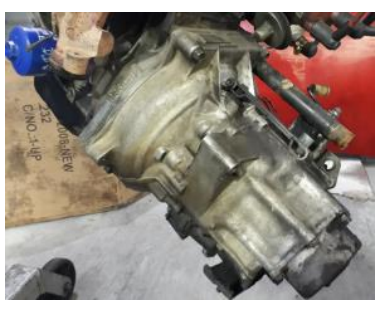

motor-gearbox

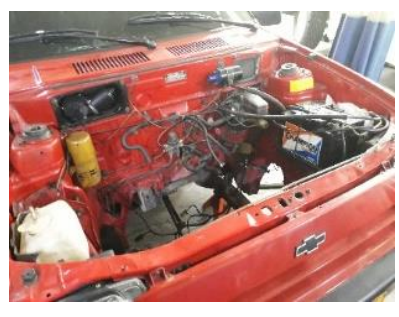

Vehicle without combustion motor
Fig. 9. Disassembly of combustion engine.

\section{E. Assembly of motor-gearbox and components}

A coupling is necessary to assemble the electrical motor and gearbox. In this conversion, we will not use clutch (as if it was automatic car), only accelerator and brake. A good design of a supporting plate and a coupling is required to guarantee concentricity of motor. Fig. 10 shows designed parts and the assembly to motor.

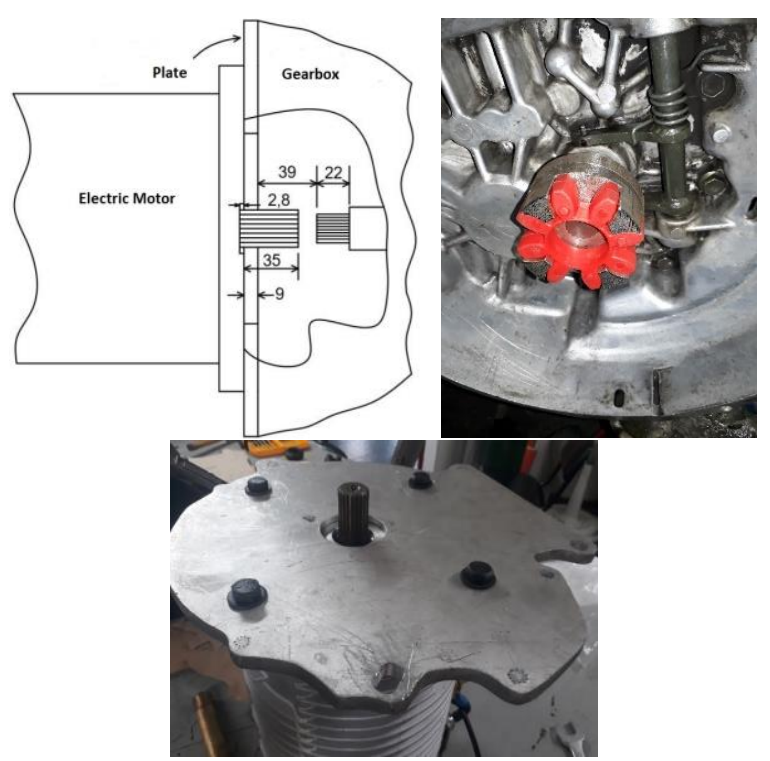

Fig. 10. Designed plate and coupling and assembly to motor

The centre hole of the plate fits in the front frame of the electric motor and ensures a perfect adjustment and greater mechanical strength. Movement tests with motor-gearbox assembly were made to measure current, a $10 \%$ current increase attested for an accepted coupling.

The final assembly was mounted in the vehicle, using the same supports of the combustion engine (Fig. 11). Location of different parts of the system was based on 3D model, considering dimensions, ventilation and protection. Battery 
was placed in the car trunk, near to system load whose connector was placed in the original fuel filler inlet (Fig. 11). Other components were located near to the motor, in front of the car, avoiding affections in the inner space of the car.

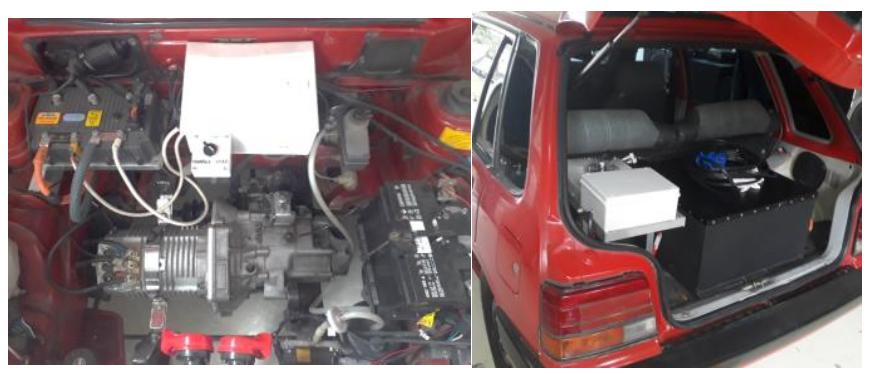

Fig. 11. Components installation

A control circuit was developed to supply tension signals with vehicle principal switch (with relays), $72 \mathrm{Vdc}$ to power (electric motor controller) and $12 \mathrm{Vdc}$ to energize peripheral components (lights, horn, fans of controller and loader, brake vacuum pump). In addition to control, protection breakers were used for the charging circuit and general system. Fig. 12 shows an overall scheme of the circuit.

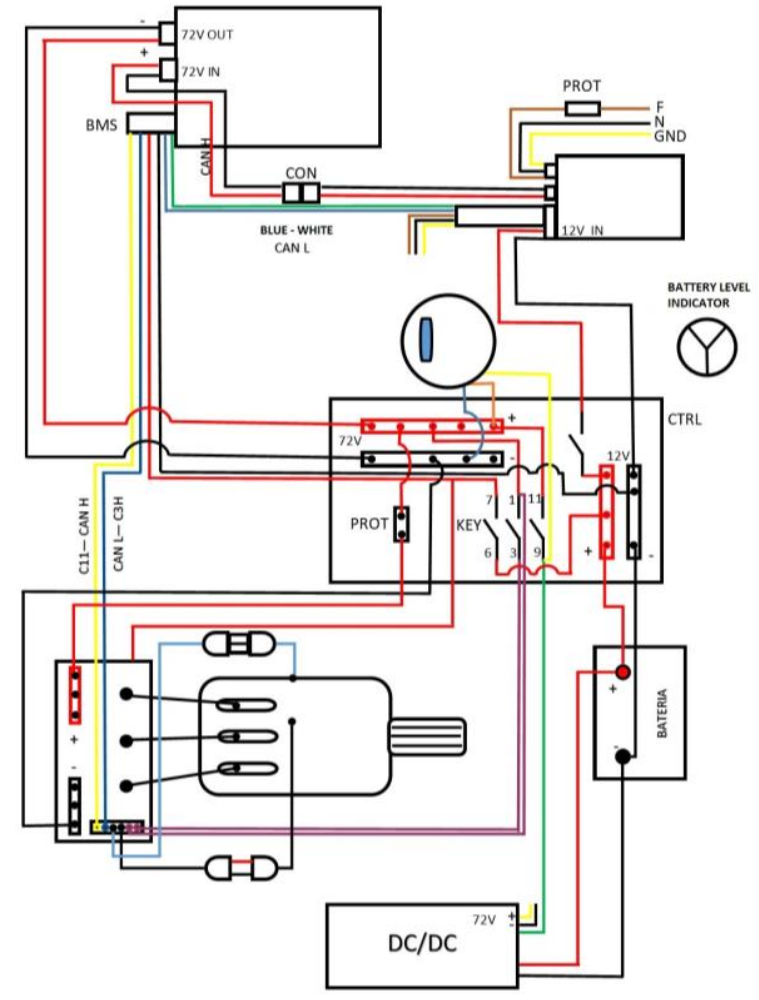

Fig. 12. Electric circuit

\section{PERFORMANCE TESTS}

Performance tests of electric motor determined power behavior and energy consumption. Tests took place before and after conversion at the dynamic tests laboratory of Technological University of Pereira developing dynamometric tests and the corresponding curves of torque and output power. The chassis dynamometer used was a $400 \mathrm{HP}$ - $2000 \mathrm{Nm}$ Dynapack with certificate of calibration by manufacturer (Fig. 13a).

Fig. 13a. Assembly of Chassis dynamometer

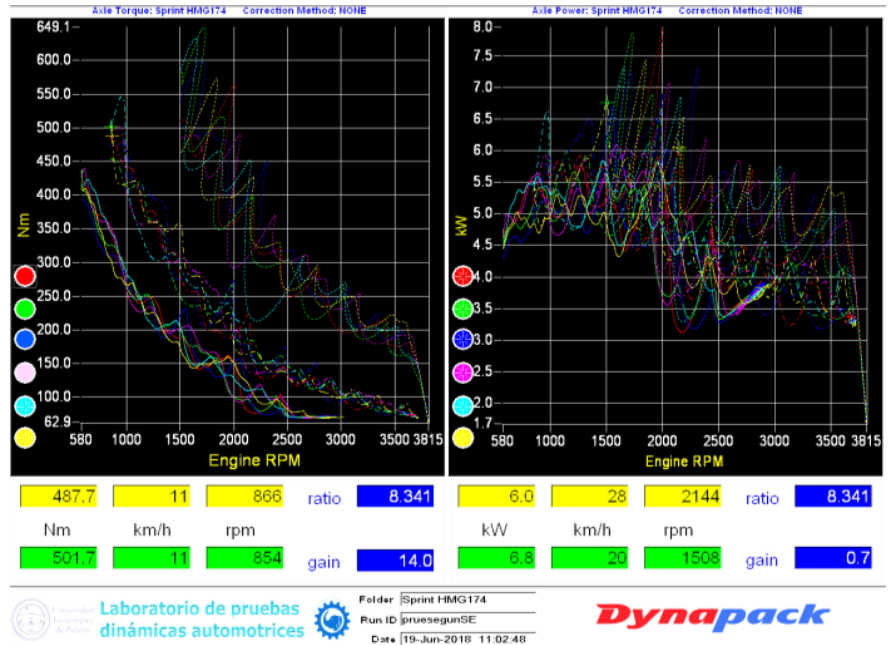

Fig. 13b. Rollers and dynamometer mounting and power curves in traction wheel

Output power in traction wheel was measured with $1^{\text {st }}, 2^{\text {nd }}$ and $3^{\text {rd }}$ gears with a range of maximum input powers from 5,5 to $6,5 \mathrm{~kW}$ (due to the loss in transmission and motor efficiency). Obtained power curves (Fig. 13) are related to the characteristic motor curve (Fig. 7), considering that relationship between RPM's of engine and drive wheel are equivalent to the transmission ratio of the tested gears. Fig. 14 illustrates the comparison between the obtained experimental curve in $3^{\text {rd }}$ gear and the factory default power motor curve. 


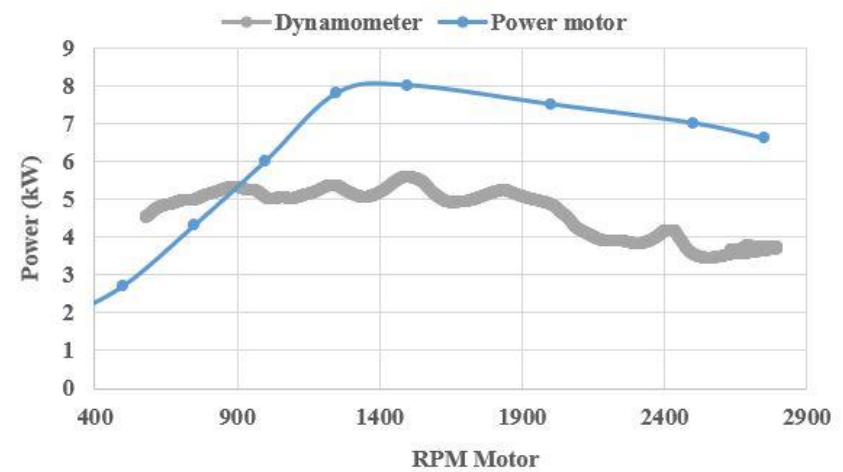

Fig. 14. Output power on traction wheel (dynamometer) and motor power

Maximum output power of motor is found at 1400 RPM, from this point onwards, output power tends to decrease. There is a loss of power due to the gearbox, being greater at high speeds (more than 20\%).

\section{Roller test}

NEDC roller bench test was performed to measure the autonomy levels. The Resulting autonomy values indicate a complete battery discharge after $250 \mathrm{~km}$, maximum speed of $80 \mathrm{~km} / \mathrm{h}$ and maximum consumption $8 \mathrm{~kW}$, validating theoretical power curve of Fig. 5. Fig. 15 shows roller test arrangement.

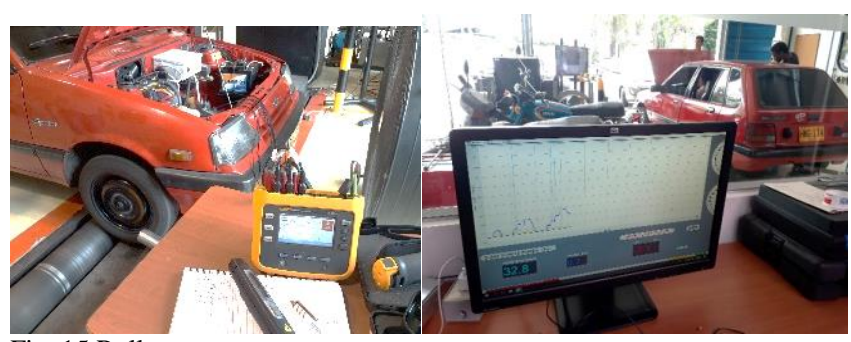

Fig. 15 Roller test

\section{Road tests}

Road test simulated real driving conditions to determine autonomy and power/energy demands. The validation theoretical power curve of Fig. 5 included load, slope, rolling and velocity.

Autonomy test: A $100 \mathrm{~km}$ flat journey was travelled at a constant speed of $40 \mathrm{~km} / \mathrm{h}$. Traveling five times the same path of $20 \mathrm{~km}$ from La Virginia to detour Unión/Anserma (Fig. 16).
Fig. 16. Route and path of autonomy test

Fig. 16 reports average power consumption of $2837 \mathrm{~kW}$ during autonomy test. Initial and final voltages were $82 \mathrm{Vdc}$ and $72,5 \mathrm{Vdc}$ respectively. Extrapolation of data would project an autonomy of $200 \mathrm{~km}$ taking into account the minimum operational voltage of the system $(62 \mathrm{Vdc})$.

Fig. 17 shows a transitory power demand in the beginning, necessary to reach nominal velocity of $40 \mathrm{~km}$. Total energy consumption was $5600 \mathrm{Wh}$, at a rate of $56 \mathrm{Wh} / \mathrm{km}$. Extrapolation of data would project a consumption of 11,2 $\mathrm{kWh}$ for a theoretical test of $200 \mathrm{~km}$.

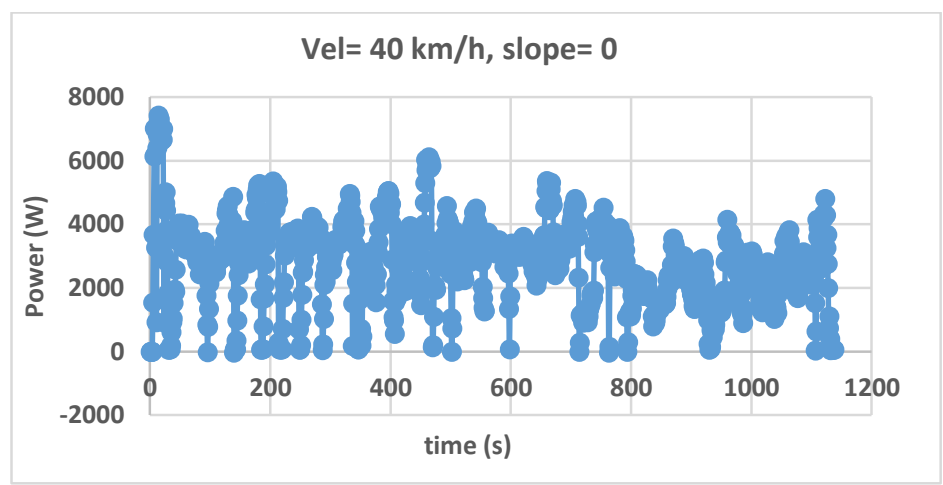

Fig. 17. Power demand during road test (flat journey)

Road test (journey with slopes): the vehicle performance on downhill and uphill paths was evaluated with passengers and the effect of regenerative braking system.

The testing route was UTP < -- > La Virginia and backwards with a total travelled distance of $70 \mathrm{~km}$, downhill energy consumption (UTP-Virginia) of $4085 \mathrm{kWh}$ with a rate of 122 $\mathrm{Wh} / \mathrm{km}$ and uphill energy consumption (Virginia-UTP) of $7932 \mathrm{kWh}$ with a rate of $236 \mathrm{Wh} / \mathrm{km}$. these values are based on power demand curves of Fig. 18. Taking into account the traction dynamics (equation 1), the demanded power reaches 8 kW approximately.

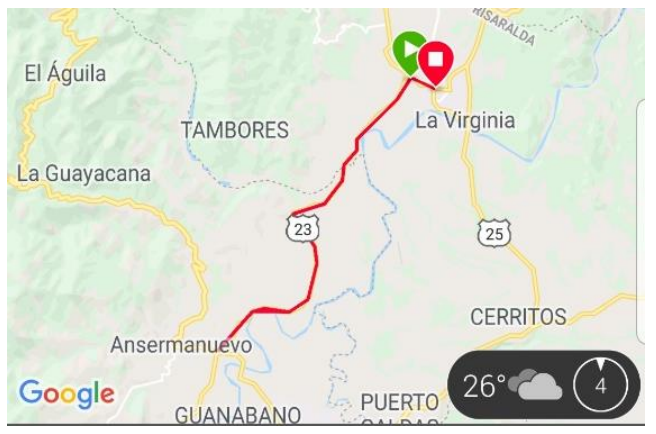




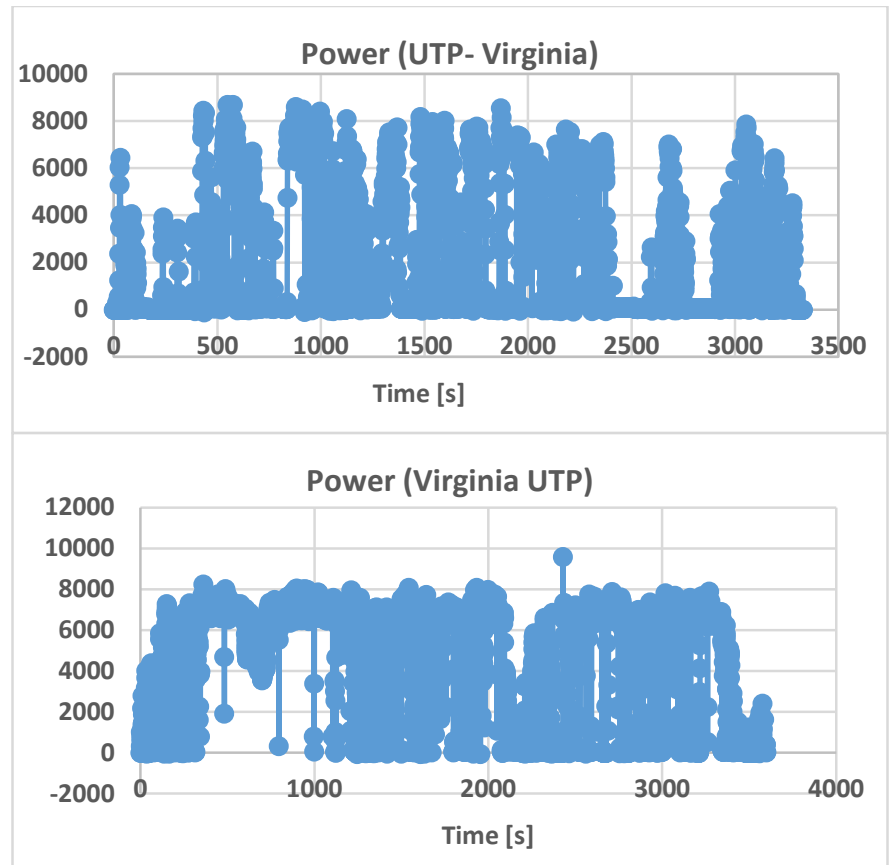

Fig. 18. Uphill and downhill energy consumption

The velocity and altitude curves (Fig. 19) allow to estimate the acceleration during the route. As an instance, an acceleration of $0,8 \mathrm{~m} / \mathrm{s}^{2}$ is required to increase speed from 30 to $60 \mathrm{~km} / \mathrm{h}$ in 10 seconds.

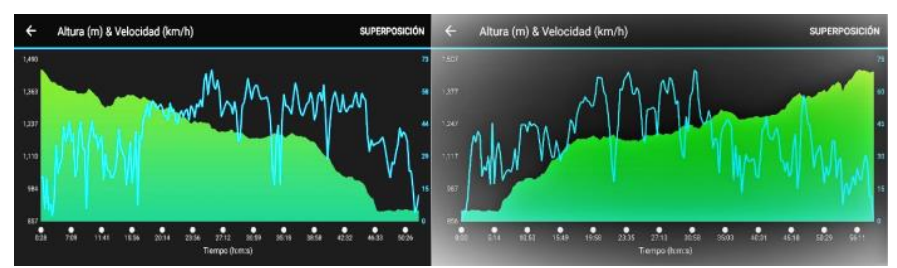

Fig. 19. Altitude and velocity curve

On the uphill path, the more challenging conditions of the road, the higher power and torque demands. Registered curves corroborated the traction dynamic model (Equation 1).

\section{Urban test}

The vehicle was evaluated in one-hour journey on Pereira streets (daylight traffic). Fig. 20 illustrates the travelled route, average slopes of 5\%, altitude range was from 1270 to $1450 \mathrm{~m}$ a.m.s.l. Total travelled distance was $20,63 \mathrm{~km}$ at an average speed of $15,5 \mathrm{~km} / \mathrm{h}$ with a total energy consumption of 2780 Wh corresponding to $1 / 4$ of the battery total capacity (134 $\mathrm{Wh} / \mathrm{km})$.

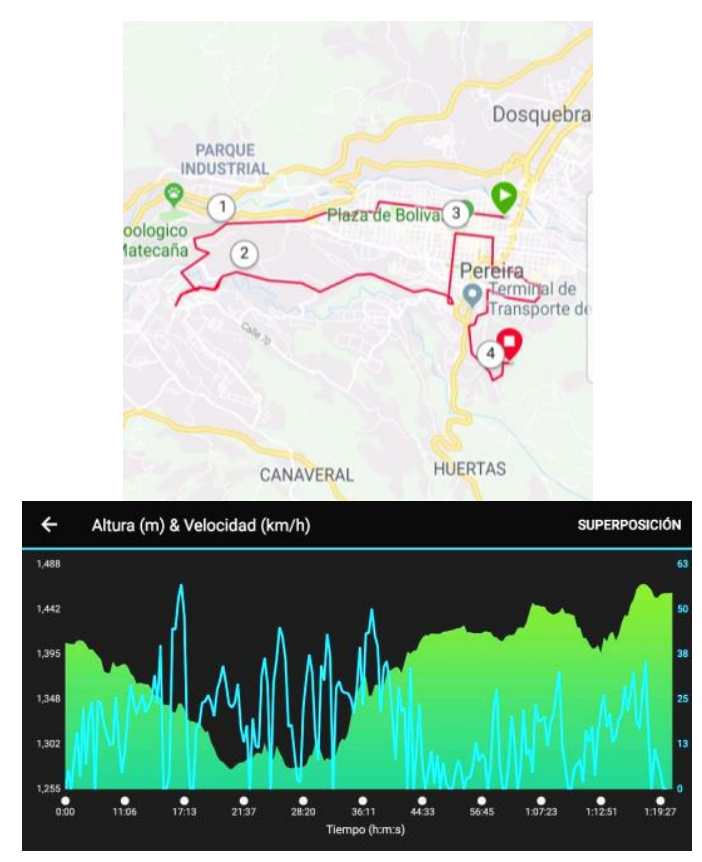

Fig. 20. Altitude speed profile during urban test

\section{CONCLUSIONS}

Vehicle autonomy on a flat journey and at a constant speed was $200 \mathrm{~km}$ with a total energy consumption of $11 \mathrm{kWh},(72$ $\mathrm{Vdc}$ and $150 \mathrm{Ah}$ ). However, according to tests performed, the autonomy may vary depending on load condition.

Electric conversion of cars prevents contamination owing to fuel burning in traditional engines. In the case presented herein, the renunciation of $6,54 \mathrm{~L}$ per $100 \mathrm{~km}$ avoided emissions to the atmosphere of CO: $180,8 \mathrm{~g}$ and THC + NOx: $65,2 \mathrm{~g}$.

Electric components represent a total weight reduction of 54 $\mathrm{kg}$ approximately, decreasing the demands of both motor output and load powers.

As far as cost savings are concerned, the value of $50 \mathrm{Wh} / \mathrm{km}$ is 0,0085 US in comparison to the price of $0,071 / \mathrm{km}(0,045$ US) representing a saving of $80 \%$.

\section{REFERENCES}

[1] P. J. Landrigan et al., "The Lancet Commission on pollution and health". The Lancet, vol 391, Issue 10119, pp 462-512, February 03, 2018. Published: October 19, 2017. DOI: 10.1016/S01406736(17)32345-0

[2] U.S. Department of Transportation Federal Transit Administration. "Public Transportation's Role in Responding to Climate Change". Updated January 2010.

[3] J. Vidal, "Air pollution rising at an 'alarming rate' in world's cities". The guardian magazine. May 12, 2016. [Online]. Available:https://www.theguardian.com/environment/2016/may/12/airpollution-rising-at-an-alarming-rate-in-worlds-cities

[4] M. Rodriguez et al. "Estudios sobre el desempeño de Vehículos Eléctricos Dependiendo de la Arquitectura de su Sistema de Tracción", Thesis, Facultad de Ingeniería Eléctrica y Electrónica, Universidad Pontificia Bolivariana, Medellín, Antioquia, Colombia, 2015 [Online]. 
Available

https://www.researchgate.net/publication/278666924_Estudios_sobre_el _desempeno_de_Vehiculos_Electricos_Dependiendo_de_La_Arquitectu ra_de_su_Sistema_de_Traccion/download

[5] S. J. González et al. "Proyecto de conversión de un automóvil de combustión interna en eléctrico", ULPGC - Universidad de Las Palmas de Gran Canaria [online]. Availablehttps://www.google.com/url?sa=t\&rct=j\&q=\&esrc=s\&source= web\&cd=1\&ved=2ahUKEwjR1qeGo7TiAhVEvlkKHfGJDowQFjAAeg QIABAC\&url=https $\% 3 \mathrm{~A} \% 2 \mathrm{~F} \% 2 \mathrm{Faccedacris}$.ulpgc.es\%2Fbitstream\%2 F10553\%2F4219\%2F1\%2F0586137_00000_0000.pdf\&usg=AOvVaw3 WU7J_sa-mYAouTrikBYR-\&cshid $=1558704654776501$

[6] D. A. Duque, J. A. Rocano, "Determinación de la autonomía del vehículo eléctrico mediante ciclos controlados". Trabajo de titulación del Título de Ingeniero Mecánico Automotriz, Universidad Politécnica Salesiana sede Matriz Cuenca. 2018. [online]. Available https://dspace.ups.edu.ec/bitstream/123456789/15067/1/UPSCT007435.pdf

[7] A. P. Asimakopoulos et al. "Experience derived from the conversion of a conventional car to a hybrid electric vehicle -analysis of the powertrain". IEEE, 09 August. 2010.

DOI: $10.1109 /$ SPEEDAM.2010.5542277

[8] Mustafa Karamuk, et al. "Electric Vehicle Powertrain Development Conceptual Design and Implementation". International Conference on Automotive and Vehicle Technologies-AVTECH-2013, Yildız Technical University-Istanbul-Turkey.

[9] Pedrosa, D. et al. "A Case Study on the Conversion of an Internal Combustion Engine Vehicle into an Electric Vehicle". IEEE Vehicle Power and Propulsion Conference, pp. 1-5, Coimbra Portugal, Oct. 2014. Available http://ieeexplore.ieee.org/xpl/abstractAuthors.jsp?reload=true\&arnumber $=7006994$

[10] Salazar, E. Arroyave, J. Vásquez, A. "Diseño y construcción de un vehículo solar híbrido". UTP. 2016. Available: http://repositorio.utp.edu.co/dspace/handle/11059/10302

[11] Delphi, Troy Michigan. "Worldwide Emissions Standards - Passenger Cars and Light Duty", 2017-2018. [Online]. Available: https://d2ou7ivda5raf2.cloudfront.net/sites/default/files/inline-

files $/ 2017 \% 202018 \% 20$ Worldwide $\% 20$ Emissions $\% 20$ Standards $\% 20 \mathrm{Pas}$ senger\%20Cars\%20Light\%20Duty.pdf

[12] R. N. Jazar, "Vehicle Dynamics, Theory and Application". Melbourne Australia: Springer, 2008. DOI:10.1007/978-0-387-74244-1

[13] J. A. Peças, F. J. Soares, P. M. Rocha. "Integration of Electric Vehicles in the Electric Power System". Proceeding of the IEEE, vol 99, Issue 1, pp 168-183, Jan. 2011. DOI: 10.1109/JPROC.2010.2066250

[14] K. Clement-Nyns, E. Haesen, J. Driesen. "The Impact of Charging Plug-In Hybrid Electric Vehicles on a Residential Distribution Grid". IEEE transaction on Power system, vol 25, Issue: pp 371-380, 1, December. 2009. DOI:10.1109/TPWRS.2009.2036481

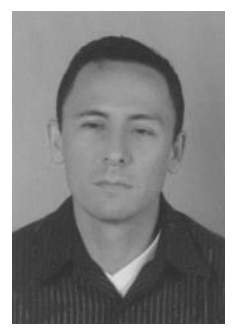

Edgar Alonso Salazar Marín.He was born on June 6, 1973 in Santa Rosa de Cabal. (Risaralda / Colombia). He's Mechanical Engineer and did doctored studies in Polytechnical University of Catalonia- Spain (2003-2007), He has postgraduate studies in master's in mechanical engineering of Andes University- Bogotá (1997-1998) and Master in Automatic Systems of Production - UTP (2002-2004). He worked as researcher in Coffee Research National Center (Cenicafé) from 1999 to 2000.

He has worked as professor in Technology Faculty, Mechanical Technology program on Technological University of Pereira since 2000 and he has developed different projects about renewable energies, like Solar systems (thermal and photovoltaic), solar vehicles and currently he has come working in electric vehicles, its viability, conversion from combustion vehicles to electric vehicles, studying different factors that influence over traction dynamic.

ORCID: https://orcid.org/0000-0003-2873-245X

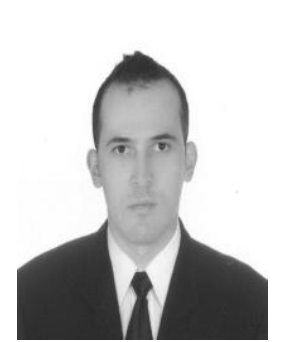

Juan Felipe Arroyave Londoño. He was born on April 18, 1977 in Calarcá (Quindio / Colombia). Mechanical Engineer and Master in Automatic Production Systems; he's professor Full time with teaching, research and extension activities at the technology Faculty at the University of Technology of Pereira. Currently he works in different simulation problems. Particularly, he's focused on aerodynamics analysis of converted electric vehicle. ORCID: https://orcid.org/0000-0002-6422-982X

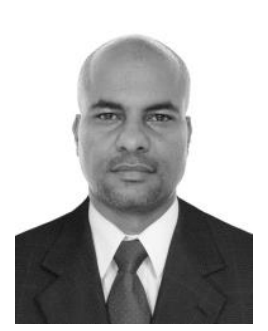

Ivan Yesid Moreno Ortiz. He was born on August 6, 1968 in the municipality of Marmato. (Caldas / Colombia). He has a bachelor's degree in mechanical engineering (2003) and a master's degree in automatic production systems (Universidad Tecnológica de Pereira) (2011). He worked as a machine operator in manufactures of Aluminum SAS (Madeal) from 1993 to 1995. Manisol SA from 1991 to 1993. Bavaria SA from 1988 to $1991 \mathrm{He}$ has worked as a professor in the Faculties of Mechanical Engineering and Technology at the Technological University of Pereira since 2003 and has collaborated in different projects on renewable energies, such as the conversion of an internal combustion vehicle to electric, currently, runs a hotbed of research and training in computerized numerical control.

ORCID: https://orcid.org/0000-0002-8276-1959 